\title{
sciendo
}

\section{Exploring the impact of customer experience on customer loyalty in e-commerce}

\author{
Ana-Maria URDEA \\ Transilvania University, Brașov, România \\ ana.urdea@unitbv.ro \\ Cristinel Petrişor CONSTANTIN \\ Transilvania University, Brașov, România \\ cristinel.constantin@unitbv.ro
}

\begin{abstract}
In recent years, with the remarkable growth of the global digital market, specialists took a new direction of focus in the field of marketing, considering customer experience an important differentiator in today's digital landscape. In an online setting, in contrast to traditional marketing, the dimensions of customer experience include informativeness, entertainment, social presence and sensory, elements that create customer value. The experience is an increasingly significant component in defining the success of an online company, becoming a source of competitive advantage for any e-business. Yet, to accomplish these favorable results, a business needs to focus on customer loyalty, a concept that is understood from a relational perspective as the consumer's preferences to sustain a stable relationship with the brand, fact that involves consistent visits of the site, and in consequence, repeat purchases. The research presented in this paper is based on the literature review. Subsequently, a conceptual model was proposed as the intersection of the online customer experience dimensions with the concept of customer loyalty, which, in turn, includes consumer's attitudes and behaviors toward an online business. The purpose of this study is twofold: (1) to offer an outline of opportunities to use customer experience for increasing customer loyalty and (2) to provide managerial implications and guides future research opportunities to empirically measure the impact of online customer experience components on customer loyalty.
\end{abstract}

Keywords: customer experience, customer loyalty, e-commerce, digital marketing strategy, marketing communication.

\section{Introduction}

The Internet's phenomenal growth emerges "as both a distribution and communication channel" changing the lives of modern society (Beig \& Khan, 2018), offering a new suitable platform for a range of businesses to trade products and services. As we can observe on the recent statistical data, due to the evolution of the digital market, the e-commerce landscape shows that there are over 2 billion digital buyers and over USD 4 trillion in sales worldwide in 2020 (Statista, 2020). Digitalization has offered new opportunities for online customers to interact with an e-business (Rose et al., 2011), on platforms such as a business website or social communication channels like Facebook, Youtube, and Instagram. Moreover, marketing is a very dynamic field where emarketers should keep up with the new trends. Recently, contemporary marketing evolved because of the impact of high international or local competition through new technology inventions that can be implemented as marketing tools (Alghizzavi, 2019). Therefore, the emergence of digital marketing has been determined by the virtual space and all the opportunities for direct communication between a company and its consumers. In the setting of online purchases, online customer experience becomes the main strategy for practitioners (Rose et al., 2011), while implementing an evolving marketing concept. Satisfactory customer experiences in 
today's digital world are the managers' main objectives (Verhoef et al., 2009). Since the marketing practices are highly suggested to be shaped by the preferences of consumers, innovative digital technologies that provide personalized experiences to consumers should be implemented (Gentile et al., 2007; Parise et al., 2016).

In electronic retailing, "high competition, high customer requirements, and complex technology" constitute "the current market status" (Pei et al., 2020). Yet, the importance of customer experience influential factor should be found on each experiential marketing strategy of online business because it creates value for consumers through interactions with the brand (Leonard et al., 2002). Moreover, during the online shopping process, businesses can achieve customer satisfaction and, consequently, customer loyalty (Vakulenko et al., 2019), which results in repeat purchase behavior (Anderson \& Srinivasan, 2003). Understanding, and especially building customer loyalty are crucial marketing activities for increasing the sales and the profitability of the online business (Fornell et al., 2016; Swaminathan et al., 2018). The core of loyalty is the consumer's ability to decline better offers from the competitors that try to convince them to substitute the products or services (Pratminingsih et al., 2013). The fundamental rules for enhancing customer loyalty in an online setting are not very different from the offline space, with the exception that the digital businesses should adapt and improve their strategies much faster than the traditional ones (Reichheld \& Schefter, 2000).

This article aims to develop a theoretical framework on the relationship between customer experience and customer loyalty. As an explanatory study, it includes the effect of four-scale dimensions of customer experience, such as informativeness, entertainment, social presence, and sensory (Bleier et al., 2019) on customer loyalty components, attitude, and behavior. The practical importance of this paper lies in determining what elements create customer experience value that might increase customer loyalty. Thus, the following research questions might be addressed:

Q1. What effect might online customer experience dimensions have on each of the elements of customer loyalty?

Q2. How does each type of online customer experience dimension influence a customer's loyalty?

The research aims to create a clearer vision in implementing the digital marketing strategy based on customer experience with customer loyalty. The research questions try to identify the challenges in achieving the online companies' digital performance, whose answers intend to guide the marketing specialists into developing a stable relationship between the businesses and their consumers using digital experiences. After analysis of theoretical perspective, the study resulted in a conceptual framework that emphasizes the impact of customer experience on customer loyalty in e-commerce. The identification of gaps in the literature leads the authors to provide directions for future research, along with managerial implications that might improve the experiential marketing strategies.

\section{Literature review}

\section{Online customer experience}

Nowadays, customer experience is a principal marketing tool that represents the evolution of the relationship occurring between a brand and its consumers' interactions (Gentile et al., 2007). This relatively new concept is a strategic process of consumer value creation through multiple memorable experiences (Jain et al., 2017). In support of this, Shaw (2007) argued that the consumer online experience is a combination of the company's physical performance and all the 
senses and emotions aroused. Even more complex, the concept of consumer experience can be defined as the outcomes that result after multiple interactions across brand touchpoints engaging sensory, affective, intellectual, and behavioral experiences (Brakus et al., 2009). From a managerial side, it is noted that customer experience is a part of the marketing scheme that focuses on building and implementing the experiences (Bolton et al., 2018), after the needs of consumers are identified (Jackson \& Ahuja, 2016).

We live in the experience economy where the experiential marketing strategy is changing at the same time as digital evolution. This era contributes to the development of the concept of online customer experience that refers to psychological state manifested after repeated exposure to an online brand ( $\mathrm{Li}$ et al., 2001; Rose et al., 2012). Therefore, the consumers form an impression about a brand as a result of cognitive and affective components from the website or social media platforms (McLean, 2017), a fact that provokes marketing specialists to create a range of stimuli based on useful text-based information, appealing visual imagery, promotional video, or audio content (Rose et al., 2012). The extant literature strongly supports the importance of customer experience, offering some factors that might influence the online experience, such as platform design, the level of interactivity, personalization, emotional states, or even past experiences. Thus, the question is how digital companies create a pleasant online experience for their consumers. The answer might be found in the online customer experience framework of Bleier et al., (2019) that includes informativeness, entertainment, social presence, and sensory appeal as main components of the experiential marketing strategy.

In this setting, informativeness is one of the cognitive characteristics of the online experience that helps the consumer in the decision-making process, involving thinking, problemsolving orientation, and mental processes (Gentile et al., 2007). Besides the utilitarian considerations of the online customer experience, entertainment represents the affective dimension, offering pleasure, fun, and play (Babin et al, 1994; Mathwick \& Malhotra, 2001) on the platform that can be the company website or the social media channels. To bring the benefits of physical experiences, the dimensions of social presence should be found on the platforms, providing the warm feelings of human touch, and friendliness (Gefen et al., 2003). Lastly, the sensory dimension of the online customer experience has the role to stimulate as many senses as possible (Bleier et al., 2019). Even if the digital environment limits the role of sensory component, arising the challenge to replicate the sensations that a consumer might have when he or she experiences a product-trial (Rohm \& Swaminathan, 2004), with the help of today's innovative digital technology a multisensory experience can be implemented that can be evoked through imagery (Brakus et al., 2009; Elder et al., 2017).

\section{Online customer loyalty}

The concept of customer loyalty refers to the sustainable relationship between a customer and a company together with its products. Loyalty represents the customer's resistance in front of external pressure, being supported by positive emotions toward the e-business, despite the variety of other companies' marketing strategies (Aspinall et al., 2001). Although the theoretical foundation of both offline and online loyalty is similar, there are some differences in the digital setting. Online loyalty is an evolved concept of traditional loyalty that has developed together with the evolution of online marketplaces, a concept that represents the customer's favorable attitude towards a brand (Kandampully et al., 2015). Moreover, the literature refers to loyalty as the action of repeat purchasing from a specific website (Srinivasan et al., 2002), being likely for the customer to remain loyal to the same e-business (Al-Adwan \& Al-Horani, 2019). 
A consumer is more consistent with the preferences for a brand when the personal needs are fulfilled. Therefore, e-businesses have the opportunity to create a customer positive experience in an electronic environment that might encourage customers to return to the shopping platform in the future, capturing their loyalty at the same time (Luo et al., 2011). The companies have their website as a tool to sustain profitable relationships with their digital consumers who are significant to a business. It was discussed a few decades ago that loyal consumers help a company to reach its main purpose, which is generating profit (Keiningham et al., 2007). Therefore, an online business should analyze all the aspects that might affect customer loyalty and satisfaction.

The significance of customer loyalty lies in the two dimensions that were early suggested: customer behavior and customer attitude (Mohammad et al., 2015). The behavioral component refers to repeat purchases and word-of-mouth marketing (Shafiee \& Bazargan, 2018). On the other side, the attitudinal component includes the consumer commitment to sustain the valued relationship with the brand, trust, and a positive emotional attachment (Luo et al., 2011). Thus, customer loyal is a result of the development of a positive attitude that leads to positive behavior. In this review article, online customer loyalty refers to a stable and favorable customer attitude and behavior regarding a specific online brand, involved in repeat purchasing of online products or services. Moreover, digital businesses are aware of the fact that is harder and less efficient to get a new customer than to retain the old ones, the cost difference being from 5 to 25 times higher for gaining new customers (Amy Gallo, 2014). Therefore, to retain the customers, we tend to believe that the strategy to design customer experience in a digital setting might evoke attitudes and behaviors that directly impact customer loyalty.

\section{Methodology}

The focus of this paper is on determining the current state of knowledge in the field of online customer experience and customer loyalty. Moreover, for a better understanding of the link between these concepts, we proposed a research model that focuses on customer experience dimensions such as, informativeness, entertainment, social presence, and sensory, each connected with the two components of customer loyalty, behavior, and attitude, offering the avenue for future research. Most of the studies selected for this literature review were found by searching on the databases for the search terms "customer experience", "customer loyalty" together with "ecommerce", "digital" or "online" that were required to be present in the title, abstract, or keywords. The criteria used for article selection are presented in See Table 1.

Table 1. Inclusion and exclusion criteria

\begin{tabular}{|l|l|}
\hline \multicolumn{1}{|c|}{ Inclusion criteria } & \multicolumn{1}{|c|}{ Exclusion criteria } \\
\hline $\begin{array}{l}\text { 1. It must have customer experience as the main } \\
\text { component. }\end{array}$ & 1 Editorials and reviews are excluded. \\
\hline $\begin{array}{l}\text { 2. The article must focus on the elements that enhance } \\
\text { customer loyalty. }\end{array}$ & $\begin{array}{l}\text { 2. Articles that mention the terms "customer experience" } \\
\text { or "customer loyalty", but they are not covering digital } \\
\text { topics. }\end{array}$ \\
\hline
\end{tabular}

Source: Authors' own research.

\section{Results and discussions}

Today, the internet is a platform that supports a very dynamic market for companies that, in the lack of physical presence, need to provide distinctive virtual customer experience as a 
consequence of the fact that all the digital technologies change consumers' needs, expectations, and behavior (Lemon \& Verhoef, 2016). And as Bleier et al., (2019) proposed, online customer experience may be designed based on the presented dimensions. For a better understanding of the relationship between online customer experience and customer loyalty, we developed a research model (see Figure 1). This theoretical framework is to be tested through future quantitative research aimed at revealing the relationships between the proposed dimensions.

PICBE | 676

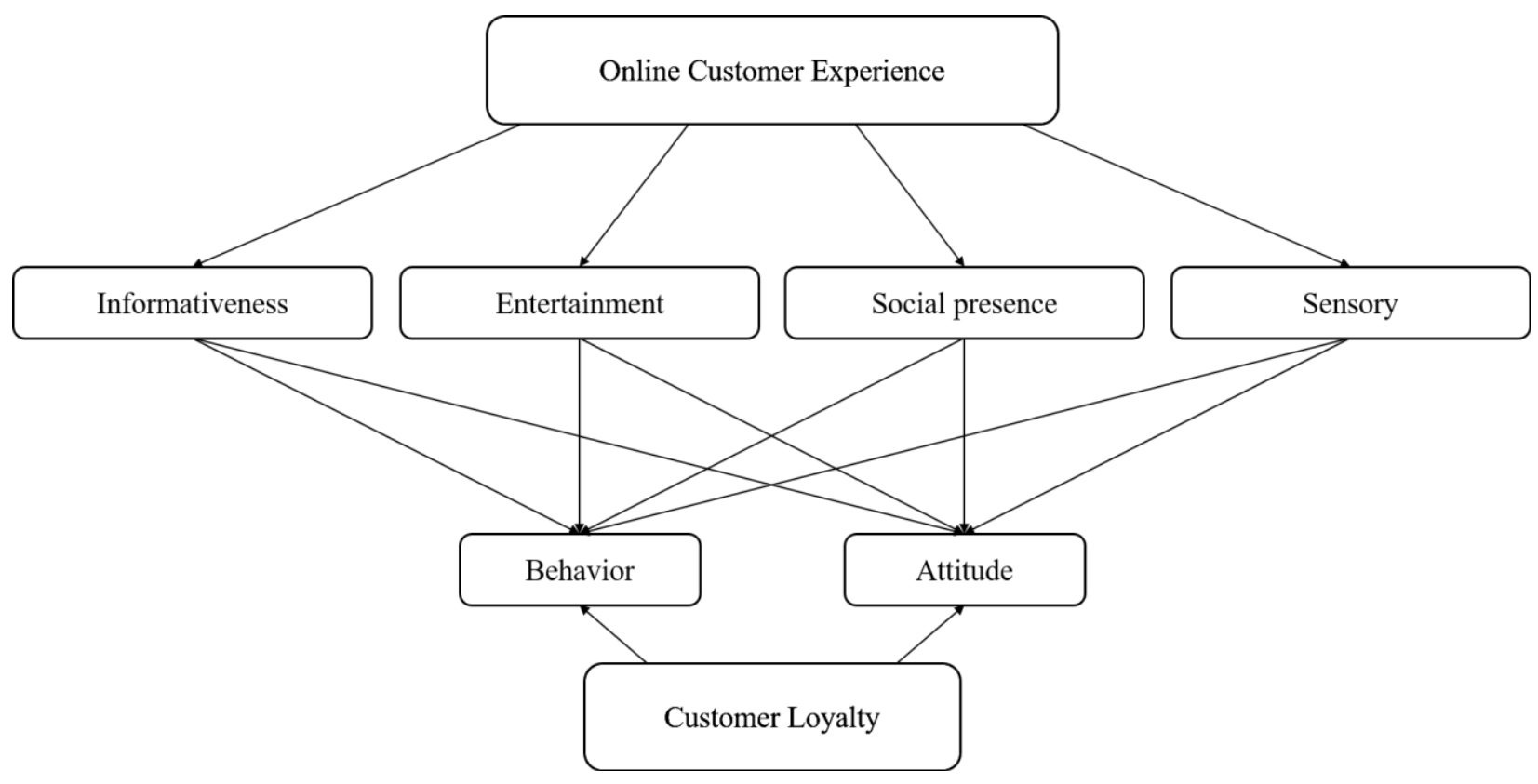

Figure 1. Customer loyalty experience framework

Source: Authors' own contribution.

Informativeness, as an online store characteristic, refers to the information content that supports customer buying activity throughout the customer journey on a website. (Hoekstra et al., 2015). Therefore, to provide the necessary information for customers, a website should include an appealing website design, enhance brand familiarity, and provide fundamental product information such as price, description, quality, and composition (Hasley \& Gregg, 2010; Wu et al., 2019). All this product-related information should be "useful, interesting, or engaging" to form a positive attitude about a brand if the content is helpful for customers who want to achieve their purchasing goals, an attitude that has a powerful influence on behavior (Shrivastava, 2017).

Digital entertainment refers to the business's capability to satisfy customers' "aesthetic enjoyment and hedonistic pleasure" (Luo, 2002), blending interactivity with the website content using elements such as colors, sounds, animated videos, and video chat communications. These elements definitely will make the consumer exploring more time on the website. Given this, the business that provides entertainment experiences during the customer's purchase process can observe that online customer activities and the average time consumers spent on the website are increasing. If the customers are entertained, we tend to believe that their attitude and behavior will be positive. In establishing positive attitudes and behaviors, an organization should offer "human-like factors" on their online platform (Kang \& Lee, 2016). The extant literature strongly supports the importance of this dimension in an online context because the impression of a brand 
may be positively changed. Moreover, social presence may increase the "pleasure, arousal and flow" throughout all the purchases' processes that involve any consumer (Wang et al., 2007). Within a virtual environment, social presence on an online shopping website may be associated with "trust, enjoyment, and perceived usefulness" (Oh, et al., 2018). Besides, this characteristic enhances better communication between the digital brand and the consumer.

Consumers experience products and services through different sensory approaches. Digital businesses have the opportunity to attract customers and to increase their positive emotions using multisensory experiences (Bleier et al., 2019), that enhance as many senses as possible. Even though the virtual environment cannot replicate the sense of touch, there are other methods to engage the other senses to innovatively appeal to the customer and to positively increase the online shopping experience. Some of these methods include a suite of digital elements such as high-quality dynamic images and videos, sounds, haptic vibration, and others.

Customer attitude and customer behavior can be easily measured by observing the customers' actions after the interaction with a brand, actions that include repurchase intention, word of mouth, or website revisit. There is a large number of factors that may influence the retention of consumers or their repurchase intentions, but to preserve existing loyal consumers, the online business should enhance customer satisfaction (Simanjuntak, Putri, Yuliati, \& Sabri, 2020). Cumulative satisfaction resulted from customer experience increases the customers' desire to consume the same products from a producer regardless of outside factors that could influence the consumer to change the producer (Suchánek \& Králová, 2019). The customer experience strategy intends to attract customers to interact with products of an online business that will result in positive reactions (Nasution et al., 2014).

It is crucial to discover what techniques increase online customer loyalty. Implementing the discussed dimensions of customer experiences creates the advantage in front of the competition because it enhances customer satisfaction, followed by customer loyalty.

\section{Managerial implications}

Contemporary marketing has evolved along with the digital economy and technology revolution, changing the retail industry landscape. The future of consumption will be a combination of offline and online platforms, based on an intelligent supply chain designed to meet the consumers' needs that are constantly changing. In a digital setting, online businesses are now able to reach more consumers, extend the distribution chain, and optimize resources (Vakulenko et al., 2019). Yet, since today's economy is based on experience (Pine \& Gilmore, 1998) and digitalization (Kravchenko et al., 2019), online customer experience should be an essential marketing strategic factor because it affects the consumer's attitude that leads to a favorable buying behavior (Constantinides et al., 2010).

The experiential value of consumers focuses on "creating the appropriate experiences, feelings and emotions" (Smith \& Colgate, 2007). Online customer experience is recognized as an important factor in managerial practice with sustainable implications for customer relationships (Andreini et al., 2018), becoming the "main source of retailers' sustainable competitive advantage" (Pei et al., 2020). Furthermore, the importance of customer loyalty lies in the competitive advantage that a business can reach (Luo et al., 2011), generating lasting revenue and profits, reducing the cost of reaching new customers. For gaining digital performance, companies should create unique online experiences designed to help achieve the business goals, grow the online presence and get a competitive advantage in front of competitors (Veríssimo \& Menezes, 2015). 
The role of the e-commerce website is to guide the customer journey with the help of the website design, navigation style, information quest, customer service, and other elements that might influence the level of customer satisfaction (Havír, 2017). Besides the website, online businesses use social media to replace traditional communication channels (Ziyadin et al., 2019), especially for creating customer experience by triggering interactions between brands and their potential customers (Pansari \& Kumar, 2017). It has been examined that consumers that engage with a company on social media influence the level of satisfaction and loyalty (Gummerus, Liljander, Weman, \& Pihlström, 2012). Moreover, to create memorable customer experiences, online businesses should adopt innovative digital technologies, such as virtual, augmented, and mixed reality technologies (Flavián et al., 2019), artificial intelligence (Ameen et al., 2021), and others. All these digital tools provide a personalized experience, allowing the customer to interact with the online business in an enjoyable experience (Parise et al., 2016).

An organization should acquire experiential marketing knowledge to anticipate the needs, demands, and expectations of customers regarding the experience they want to be involved in. As discussed, the importance of customer experience lies in the impact on a business's bottom line. For example, there is a tight relationship between how consumers feel about a brand and customer experience, retention, and loyalty. Organizations should distinguish their products and services from others on the digital market through a specific design of customer experience across the various touchpoints.

\section{Conclusion}

Interest in the concepts of customer experience and customer loyalty in the extant literature is currently high, but online customer experience is a relatively new concept that has attracted attention only in recent years. This study aimed to create a framework of customer value creation based on online experience and its relationship with customer loyalty, contributing to the online customer experience literature, especially in enhancing customer loyalty. Moreover, this study approaches these notions from different angles exploring the impact of online customer experience on customer loyalty elements, attitude, and behavior. Therefore, we first defined the concept of online customer experience together with the four-dimension scale, and the notion of customer loyalty through attitude and behavior. The discussion offers many useful insights that focus on developing an experiential marketing strategy that might be the main determinant of customer loyalty. Therefore, this research model implies numerous strategic advice that can be used by practitioners in enhancing customer loyalty through online customer experience and subsequently, digital marketing performance.

This study has limitations, which offer directions for future research. First of all, not all relevant studies have been included in this article, studies that could have a significant impact on the field of customer experience on e-commerce. This issue resulted from the existence of a large spectrum of sources and databases. Second of all, fast-changing customer behavior could be a challenge for the selection process because all the articles were expected to bring up-to-date customer insights and relatively old papers should have been excluded. Furthermore, at this point, this study is at the stage of conceptual review, therefore, empirical research is required to test our propositions. As an extension to our analysis of literature review based on the connection between online customer experience and customer loyalty, quantitative research should be conducted to test the research questions. The variables should be formed and examined by the independent variables including online customer experience dimensions: informativeness, entertainment, social presence, and sensory, and the independent ones including the two 
components of customer loyalty: attitude and behavior. Variable measurement should be performed by questions measured on 5 point Likert-type scale, anchored from 1 - Strongly disagree to 5 - Strongly agree.

The proposed research model will hopefully serve as a framework for further researches, developing a quantitative measure of customer loyalty through online customer experience. The authors conclude this study by stating that even though online customer experience absences a physical presence such as a brick and mortar store, there are many opportunities to design a virtual customer experience with the help of innovative digital technologies that will increase customer loyalty.

\section{References}

Al-Adwan, A. S., \& Al-Horani, M. A. (2019). Boosting Customer E-Loyalty: An Extended Scale of Online Service Quality, Information, 10(12), 380.

Alghizzavi, M. (2019). The role of digital marketing in consumer behavior: A survey, International Journal of Information Technology and Language Studies, 3(1), 24-31.

Ameen, N., Tarhini, A., Reppel, A., \& Anand, A. (2021). Customer experiences in the age of artificial intelligence, Computers in Human Behavior, 114, 1-14.

Amy Gallo (2014). The Value of Keeping the Right Customers. Harvard Business Review.

Anderson, R. E., \& Srinivasan, S. S. (2003). E-satisfaction and e-loyalty: A contingency framework, Psychology and Marketing, 20(2), 123-138.

Andreini, D., Pedeliento, G., Zarantonello, L., \& Solerio, C. (2018). A renaissance of brand experience: Advancing the concept through a multi-perspective analysis, Journal of Business Research, 91, 123-133.

Aspinall, E., Nancarrow, C., \& Stone, M. (2001). The meaning and measurement of customer retention, Journal of Targeting, Measurement and Analysis for Marketing, 10(1), 79-87.

Babin, B. J., Darden, W. R., \& Griffin, M. (1994). Work and/or Fun: Measuring Hedonic and Utilitarian Shopping Value, Journal of Consumer Research, 20(4), 644.

Beig, F. A., \& Khan, M. F. (2018). Impact of Social Media Marketing on Brand Experience: A Study of Select Apparel Brands on Facebook, Vision: The Journal of Business Perspective, 22(3), 264-275.

Bleier, A., Harmeling, C. M., \& Palmatier, R. W. (2019). Creating Effective Online Customer Experiences, Journal of Marketing, 83(2), 98-119.

Bolton, R. N., McColl-Kennedy, J. R., Cheung, L., Gallan, A., Orsingher, C., Witell, L., \& Zaki, M. (2018). Customer experience challenges: bringing together digital, physical and social realms, Journal of Service Management, 29(5), 776-808.

Brakus, J. J., Schmitt, B. H., \& Zarantonello, L. (2009). Brand Experience: What is It? How is it Measured? Does it Affect Loyalty?, Journal of Marketing, 73(3), 52-68.

Constantinides, E., Lorenzo-Romero, C., \& Gómez, M. A. (2010). Effects of web experience on consumer choice: a multicultural approach, Internet Research, 20(2), 188-209.

Elder, R. S., Schlosser, A. E., Poor, M., \& Xu, L. (2017). So Close I Can Almost Sense It: The Interplay between Sensory Imagery and Psychological Distance, Journal of Consumer Research, 44(4), 877-894.

Flavián, C., Ibáñez-Sánchez, S., \& Orús, C. (2019). The impact of virtual, augmented and mixed reality technologies on the customer experience, Journal of Business Research, 100, 547-560. 
Fornell, C., Morgeson, F. V., \& Hult, G. T. M. (2016). An Abnormally Abnormal Intangible: Stock Returns on Customer Satisfaction, Journal of Marketing, 80(5), 122-125.

Frederick, F. Reichheld, \& Phil Schefter (2000). E-Loyalty: Your Secret Weapon on the Web, Harvard Business Review.

Gefen, Karahanna, \& Straub (2003). Trust and TAM in Online Shopping: An Integrated Model, MIS Quarterly, 27(1), 51.

Gentile, C., Spiller, N., \& Noci, G. (2007). How to Sustain the Customer Experience, European Management Journal, 25(5), 395-410.

Gummerus, J., Liljander, V., Weman, E., \& Pihlström, M. (2012). Customer engagement in a Facebook brand community, Management Research Review, 35(9), 857-877.

Hasley, J. P., \& Gregg, D. P. (2010). An exploratory study of website information content, Journal of Theoretical and Applied Electronic Commerce Research, 5(3), 27-38.

Havír, D. (2017). A Comparison of the Approaches to Customer Experience Analysis, Economics and Business, 31(1), 82-93.

Hoekstra, J.C., Huizingh, E. K. R., Bijmolt, T. H. A., \& Krawczyk, A. C. (2015). Providing information and enabling transactions: Which website function is more important for success?, Journal of Electronic Commerce Research, 16(2), 81-94.

Jackson, G., \& Ahuja, V. (2016). Dawn of the digital age and the evolution of the marketing mix, Journal of Direct, Data and Digital Marketing Practice, 17(3), 170-186.

Jain, R., Aagja, J., \& Bagdare, S. (2017). Customer experience - a review and research agenda, Journal of Service Theory and Practice, 27(3), 642-662.

Kandampully, J., Zhang, T., \& Bilgihan, A. (2015). Customer loyalty: a review and future directions with a special focus on the hospitality industry, International Journal of Contemporary Hospitality Management, 27(3), 379-414.

Kang J. K., \& Lee W. J. (2016). Effects of sense of control and social presence on customer experience and e-service quality. Information development, 1-19.

Keiningham, T. L., Cooil, B., Aksoy, L., Andreassen, T. W., \& Weiner, J. (2007). The value of different customer satisfaction and loyalty metrics in predicting customer retention, recommendation, and share-of-wallet, Managing Service Quality: An International Journal, 17(4), 361-384.

Kravchenko, O., Leshchenko, M., Marushchak, D., Vdovychenko, Y., \& Boguslavska, S. (2019). The digitalization as a global trend and growth factor of the modern economy, SHS Web of Conferences, 65, 7004.

Lemon, K. N., \& Verhoef, P. C. (2016). Understanding Customer Experience Throughout the Customer Journey, Journal of Marketing, 80(6), 69-96.

Leonard, L. Berry, Lewis P. Carbone, \& Stephan H. Haeckel (2002). Managing the Total Customer Experience, MIT Sloan Management Review, 43(3).

Li, H., Daugherty, T., \& Biocca, F. (2001). Characteristics of virtual experience in electronic commerce: A protocol analysis, Journal of Interactive Marketing, 15(3), 13-30.

Luo, M. M., Chen, J.-S., Ching, R. K.H., \& Liu, C.-C. (2011). An examination of the effects of virtual experiential marketing on online customer intentions and loyalty, The Service Industries Journal, 31(13), 2163-2191.

Luo, X. (2010). Uses and gratifications theory and e-consumer behaviors: A structural equation modeling study, Journal of Interactive Advertising, 2(2), 34-41.

Mathwick, C., Malhotra, N., \& Rigdon, E. (2001). Experiential value: conceptualization, measurement and application in the catalog and Internet shopping environment 211 论This 
article is based upon the first author's doctoral dissertation completed while at Georgia Institute of Technology, Journal of Retailing, 77(1), 39-56.

McLean, G. J. (2017). Investigating the online customer experience - a B2B perspective. Marketing Intelligence \& Planning, 35(5), 657-672.

Mohammad, J., Taghi Pourian, Mahsa, M., Bakhsh (2015). Loyalty: From Single-Stage Loyalty to Four-Stage Loyalty, International Journal of New Technology and Research, 1(6), 48-51.

Nasution, R. A., Sembada, A. Y., Miliani, L., Resti, N. D., \& Prawono, D. A. (2014). The Customer Experience Framework as Baseline for Strategy and Implementation in Services Marketing, Procedia - Social and Behavioral Sciences, 148, 254-261.

Oh, C. S., Bailenson J. N., \& Welch, G. F. (2018). A systematic review of social presence: definition, antecedents, and implications, Frontiers in Robotics and AI, 5(114), 1-35.

Pansari, A., \& Kumar, V. (2017). Customer engagement: the construct, antecedents, and consequences, Journal of the Academy of Marketing Science, 45(3), 294-311.

Parise, S., Guinan, P. J., \& Kafka, R. (2016). Solving the crisis of immediacy: How digital technology can transform the customer experience, Business Horizons, 59(4), 411-420.

Pei, X.-L., Guo, J.-N., Wu, T.-J., Zhou, W.-X., \& Yeh, S.-P. (2020). Does the Effect of Customer Experience on Customer Satisfaction Create a Sustainable Competitive Advantage? A Comparative Study of Different Shopping Situations, Sustainability, 12(18), 7436.

Pine II, J. B., \& Gilmore, H. G. (1998). Welcome to the experience economy, Harvard Business Review. (76(4)), 97-105.

Pratminingsih, S. A., Lipuringtyas, C., \& Rimenta, T. (2013). Factors Influencing Customer Loyalty Toward Online Shopping, International Journal of Trade, Economics and Finance, 104-110.

Rohm, A. J., \& Swaminathan, V. (2004). A typology of online shoppers based on shopping motivations, Journal of Business Research, 57(7), 748-757.

Rose, S., Clark, M., Samouel, P., \& Hair, N. (2012). Online Customer Experience in e-Retailing: An empirical model of Antecedents and Outcomes, Journal of Retailing, 88(2), 308-322.

Rose, S., Hair, N., \& Clark, M. (2011). Online Customer Experience: A Review of the Businessto-Consumer Online Purchase Context, International Journal of Management Reviews, 13(1), 24-39.

Sanjay Shrivastava (2017). Digital Disruption is Redefining the Customer Experience: The Digital Transformation Approach of the Communications Service Providers, Telecom Business Review: SITM Journal, 10(1), 41-52.

Shafiee, M. M., \& Bazargan, N. A. (2018). Behavioral Customer Loyalty in Online Shopping: The Role of E-Service Quality and E-Recovery, Journal of Theoretical and Applied Electronic Commerce Research, 13(1), 26-38.

Shaw, C. (2007). The DNA of Customer Experience. London, Palgrave Macmillan UK. https://doi.org/10.1057/9780230210813

Simanjuntak, M., Putri, N. E., Yuliati, L. N., \& Sabri, M. F. (2020). Enhancing customer retention using customer relationship management approach in car loan bussiness, Cogent Business \& Management, 7(1), 1738200.

Smith, J. B., \& Colgate, M. (2007). Customer Value Creation: A Practical Framework, Journal of Marketing Theory and Practice, 15(1), 7-23.

Srinivasan, S. S., Anderson, R., \& Ponnavolu, K. (2002). Customer loyalty in e-commerce: an exploration of its antecedents and consequences, Journal of Retailing, 78(1), 41-50. 
Statista (2020). https://www.statista.com/.[Accesed on January 2021]

Suchánek, P., \& Králová, M. (2019). Customer satisfaction, loyalty, knowledge and competitiveness in the food industry, Economic Research-Ekonomska Istraživanja, 32(1), 1237-1255.

Swaminathan, S., Anderson, R., \& Song, L. (2018). Building loyalty in e-commerce: Impact of business and customer characteristics, Journal of Marketing Channels, 25(1-2), 22-35.

Vakulenko, Y., Shams, P., Hellström, D., \& Hjort, K. (2019). Online retail experience and customer satisfaction: the mediating role of last mile delivery, The International Review of Retail, Distribution and Consumer Research, 29(3), 306-320.

Verhoef, P. C., Lemon, K. N., Parasuraman, A., Roggeveen, A., Tsiros, M., \& Schlesinger, L. A. (2009). Customer Experience Creation: Determinants, Dynamics and Management Strategies, Journal of Retailing, 85(1), 31-41.

Veríssimo, M., \& Menezes, N. (2015). Social media as a tool to enhance customer experience in hospitality industry, Revista Portuguesa De Marketing, 38(34), 23-30.

Wang, L. C., Baker, J., Wagner, J. A., \& Wakefield, K. (2007). Can A Retail Web Site be Social?, Journal of Marketing, 71(3), 143-157.

Wu, R., Wang, G., \& Yan, L. (2019). The effects of online store informativeness and entertainment on consumers' approach behaviors, Asia Pacific Journal of Marketing and Logistics.

Ziyadin, S., Doszhan, R., Borodin, A., Omarova, A., \& Ilyas, A. (2019). The role of social media marketing in consumer behaviour, E3S Web of Conferences, 135, 4022. 